\title{
Implementasi Metode Tahsin Al Husna dalam Pembelajaran Jarak Jauh pada Masa Pandemi Covid-19 di SDIT Al Kahfi
}

\author{
Muhammad Arif Rahmawan \\ Prodi Pendidikan Agama Islam, Fakultas Ilmu Sosial, Universitas Negeri Jakarta \\ Email: muhammadarif_pai16s1@mahasiswa.unj.ac.id \\ Mushlihin \\ Prodi Pendidikan Agama Islam, Fakultas Ilmu Sosial, Universitas Negeri Jakarta \\ Email: mushlihin@unj.ac.id \\ Khairil Ikhsan Siregar \\ Prodi Pendidikan Agama Islam, Fakultas Ilmu Sosial, Universitas Negeri Jakarta \\ Email: khairil_siregar@unj.ac.id \\ Firdaus Wajdi \\ Prodi Pendidikan Agama Islam, Fakultas Ilmu Sosial, Universitas Negeri Jakarta \\ Email: firdaus.wajdi@unj.ac.id
}

Naskah diterima: 07 Januari 2021, direvisi: 25 Januari 2021, disetujui 26 Januari 2021

\begin{abstract}
This study aims to describe and analyze the implementation of the Al Husna method in learning tahsin at SDIT Al Kahfi Ciracas via distance learning mechanism. It seeks to answer the following questions, how was the preparation for distance learning tahsin Al-Quran using the Al Husna method, the implementation of distance learning tahsin Al-Quran using the Al Husna method, the evaluation of learning in distance learning tahsin using the Al Husna method. It also will describe the use of media in distance learning tahsin using the Al method Husna. This research used a descriptive analysis method using a qualitative approach, which was carried out from October to November 2020. Primary data collection took place at SDIT Al Kahfi Ciracas, East Jakarta. Data collection techniques include observation and interviews at SDIT Al Kahfi Ciracas, East Jakarta. Based on the results of observations and interviews conducted by researchers, distance learning Al-Quran tahsin using the Al Husna method at SDIT Al Kahfi, is implemented quite well. This can be seen from the stages in distance learning tahsin using the Al Husna method. Starting from the preparation and planning that is sufficiently well prepared with the administration of learning planning, preparation in terms of the capacity of teacher resources, as well as preparation of facilities and infrastructure to support distance learning. But, lesson planning design section was incomplete. Then, this study also shows that the implementation of tahsin distance learning using the Al Husna method was in accordance with the learning plan. Furthermore, it can also be seen from the evaluation of learning held in distance learning tahsin using the Al Husna method worked as expected.
\end{abstract}

Keywords: Al Husna Tahsin Method, Qur'an Study, Distance Learning. 


\begin{abstract}
Abstrak
Penelitian ini bertujuan untuk mendeskripsikan dan menganalisis implementasi metode Al Husna pada pembelajaran tahsin di SDIT Al Kahfi Ciracas dengan model Pembelajaran Jarak Jauh (PJJ). Tujuan penelitian ini adalah untuk mengetahui bagaimana persiapan Pembelajaran Jarak Jauh tahsin Al-Qur'an menggunakan metode Al Husna, pelaksanaan Pembelajaran Jarak Jauh tahsin AlQur'an menggunakan metode Al Husna, evaluasi pembelajaran dalam Pembelajaran Jarak Jauh tahsin dengan menggunakan metode Al Husna. Penelitian ini juga mendeskripsikan penggunaan media dalam Pembelajaran Jarak Jauh tahsin dengan menggunakan metode Al Husna. Penelitian ini menggunakan metode deskriptif analisis dengan menggunakan pendekatan kualitatif, yang dilaksanakan dari bulan Oktober hingga bulan November tahun 2020. Penelitian ini mengambil tempat di di SDIT Al Kahfi Ciracas, Jakarta Timur. Teknik pengumpulan data yang digunakan adalah observasi dan wawancara ke SDIT Al Kahfi Ciracas, Jakarta Timur. Berdasarkan hasil observasi dan wawancara yang dilakukan peneliti, Pembelajaran Jarak Jauh tahsin Al-Qur'an dengan menggunakan metode Al Husna di SDIT Al Kahfi, diimplementasikan dengan cukup baik. Hal tersebut dilihat dari tahapan yang pada Pembelajaran Jarak Jauh tahsin dengan menggunakan metode Al Husna. Mulai dari persiapan dan perencanaan yang cukup matang dengan adanya administrasi perencanaan pembelajaran, persiapan dari segi kapasitas sumber daya pendidik, juga persiapan sarana dan prasarana penunjang Pembelajaran Jarak Jauh. Hanya saja pada bagian rancangan perencanaan pembelajaran tidak lengkap. Kemudian dapat dilihat juga dari pelaksanaan Pembelajaran Jarak Jauh tahsin dengan menggunakan metode Al Husna sesuai dengan perencanaan pembelajaran yang telah dibuat sebelum dilaksanakannya pembelajaran. Selanjutnya dapat terlihat juga dari evaluasi pembelajaran yang diadakan dalam Pembelajaran Jarak Jauh tahsin dengan menggunakan metode Al Husna berjalan dengan cukup baik.
\end{abstract}

Kata Kunci: Metode Tahsin Al Husna, Belajar Al-Qur'an, Pembelajaran Jarak Jauh

\title{
A. Pendahuluan
}

Pada awal tahun 2020 proses pembelajaran di sekolah mengalami kendala disebabkan mewabahnya virus Covid-19 yang tersebar di seluruh dunia. Penyebaran virus yang sangat cepat, hingga World Health Organization (WHO) menetapkan virus tersebut sebagai Pandemi (Widyaningrum, 2020). Karena hal tersebut pemerintah Indonesia menetapkan Pembatasan Sosial Berskala Besar (PSBB) yang kemudian menjadi salah satu dasar pelaksanaan pembelajaran di sekolah harus diterapkan secara daring melalui sistem Pembelajaran Jarak Jauh (Surat Edaran Kemendikbud No. 36962/MPK.A/HK/2020).

Selama masa pembelajaran daring atau Pembelajaran Jarak Jauh (PJJ) sebagai bentuk pencegahan terhadap penyebaran virus Covid-19, hal cukup mempengaruhi pembelajaran yang ada (Amboro, 2020; Lilawati, 2020; Santoso, Deri Teguh; Sari, 2020; 
Supriadi, 2020), termasuk di dalam pelajaran tahsin (membaca Al-Qur'an dengan baik dan benar). Dalam pembelajaran tahsin Al-Qur'an, PJJ juga cukup menjadi kendala selama proses pembelajaran. Namun, pembelajaran tahsin tetap harus berjalan meskipun tidak dengan tatap muka. Karena jika pembelajaran tahsin Al-Qur'an diberhentikan selama masa PJJ, maka akan berdampak pada menurunnya kualitas bacaan Al-Qur'an peserta didik, disebabkan karena lama tidak dilatih. Karenanya, kemudian dalam pembelajaran tahsin AlQur'an, di masa Pandemi Covid-19 sekarang ini dibutuhkan cara atau metode yang menyesuaikan dengan kondisi pembelajaran secara jarak jauh (PJJ). Sehingga peserta didik tetap dapat mempelajari Al-Qur'an meskipun tidak secara langsung bertatap muka dengan gurunya, sebagai bentuk antisipasi ketersebaran virus Covid-19.

Salah satu lembaga yang berupaya untuk melakukan transformasi pada metode pembelajaran tahsin Al-Qur'an adalah SDIT Al Kahfi Ciracas. Sekolah tersebut berupaya memformulasikan pembelajaran tahsin Al-Qur'an dengan tetap menggunakan metode yang sebelumnya sudah diterapkan dalam Pembelajaran Jarak Jauh tahsin Al-Qur'an. Metode yang dipakai dalam pembelajaran tahsin di SDIT Al Kahfi adalah metode tahsin Al Husna.

Tahsin (تحسين) berasal dari kata dalam Bahasa Arab hassana-yahassinu-tahsin yang berarti baik dan bagus. Kemudian jika dilihat dari kata tahsin itu sendiri, maka artinya adalah memperbaiki atau membaguskan. Sehingga dapat disimpulkan bahwa, pembelajaran tahsin adalah upaya untuk memperbaiki bacaan AlQur'an agar sesuai dengan kaidah-kaidah hukum tajwid dan berupaya memperindah dalam pelantunan bacaannya (Setiawan, 2015). Sedangkan pembelajaran tahsin sendiri meliputi materi makharijul huruf (tempat keluarnya huruf), hukum bacaan, sifatul huruf (cara pengucapan huruf), panjang pendek bacaan, tanda berhenti (waqaf), serta ghorib (bacaanbacaan khusus di luar kaidah). Pembelajaran tahsin lebih didominasi pada aspek kognitif dan psikomotor, karena tahsin Al-Qur'an berfokus pada keterampilan. Pembelajaran tahsin Al-Qur'an yang akan dikembangkan pada penelitian ini adalah tahsin level satu. Pada level tersebut yang menjadi pokok bahasan di antaranya makharijul huruf, sifatul huruf, panjang pendek bacaan, serta hukum bacaan dengan spesifikasi pada nun sukun, tanwin, dan mim sukun.

Metode Al Husna merupakan metode untuk mempelajari cara membaca Al-Qur'an dengan baik dan benar yang dirumuskan oleh Tri Wahyudi. Metode ini cukup relevan khususnya untuk anak-anak, namun tetap bisa digunakan untuk mempelajari Al-Qur'an dari berbagai macam kalangan usia. Metode ini merupakan salah satu metode belajar baca Al-Qur'an yang mudah, praktis, dan sistematis. Metode ini sangat memudahkan terlebih 
bagi anak-anak, karena dalam pengajarannya metode ini tidak hanya berfokus pada modul pembelajaran tetapi juga pada cara belajarnya, yaitu dengan adanya cara menunjuk bacaan yang setiap huruf dan tanda baca memiliki caranya sendiri dalam menunjuk huruf tersebut, juga dengan menanamkan kepada peserta didik ciri khusus pada setiap huruf hijaiyyah dengan menggunakan istilah-istilah yang dekat dengan anak. Selain itu metode Al Husna juga tidak dirumitkan dengan menghafal berbagai macam istilah-istilah dalam kaidah ilmu tajwid, tetapi peserta didik tetap diajarkan cara membaca dari kaidah-kaidah tersebut dengan sistem penggunaan tanda baca pada mushaf Al-Qur'an. sehingga peserta didik dapat dengan mudah untuk menghafal dan memahami kaidah dan cara membaca AlQur'an melalui metode ini. Secara lebih khusus, dalam proses pembelajaran tahsin AlQur'an, dengan metode Al Husna mempelajari cara membaca Al-Qur'an dengan baik dengan menggunakan tiga cara dalam proses pembelajarannya, yaitu; penguasaan huruf hijaiyyah, penggunaan sistem tanda baca, dan penggunaan kata kunci dan kode.

Pertama, penguasaan huruf hijaiyyah . Salah satu keunikan dari metode Al Husna ini adalah dalam tahapan penguasaan huruf hijaiyyah-nya. Dalam proses ini peserta didik diajarkan dengan menggunakan teknik scanning-story-saying. Scanning adalah proses pengenalan bentuk dan ciri dari huruf hijaiyyah. Kemudian untuk memudahkan peserta didik menghafal huruf hijaiyyah yang telah di-scanning, teknik selanjutnya adalah story, atau menarasikan ciri dari huruf-huruf hijaiyyah dengan menggunakan cerita atau perumpamaan. Setelah itu peserta didik akan dicontohkan cara mengucapkan setiap hurufnya (saying). Kedua, penggunaan sistem tanda baca. Metode Al-Husna merupakan salah satu metode yang menggunakan sistem tanda baca pada penerapan ilmu tajwid saat membaca Al-Quran. Sistem tanda baca ini hanya ada pada mushaf Al-Qur'an Rosm Utsmani, yang di dalamnya terdapat ciri khusus pada tanda-tanda baca tertentu saat berlaku hukum tajwid. Ketiga, penggunaan kata kunci dan kode. Penggunaan kata kunci dan kode menjadi teknik dalam pengajaran yang diterapkan dalam metode Al Husna. Kata kunci merupakan pengelompokan huruf-huruf hijaiyyah yang disusun berdasarkan huruf-huruf yang memiliki kesamaan baik dari segi bentuk, makhraj, sifat, ataupun pengucapan hurufnya. Adapun kode adalah tanda-tanda yang di aplikasikan pengajar untuk membantu peserta didik memahami sekaligus mengingat huruf, tanda baca ataupun kaidah yang ada pada Al-Qur'an.

Dalam Pembelajaran Jarak Jauh tahsin Al-Qur'an di SDIT Al Kahfi, implementasi metode Al Husna tetap diupayakan memenuhi standar yang ada pada metode tersebut, yaitu; penerapan tiga tahapan yang ada pada metode Al Husna (penguasaan huruf, 
penggunaan sistem tanda baca, penggunaan kata kunci dan kode), dan penggunaan teknik pengajaran Al Husna (scanning-story-saying). Semua ketentuan pembelajaran yang ada pada metode pembelajaran Al Husna dikemas seefektif mungkin dalam Pembelajaran Jarak Jauh tahsin Al-Qur'an melalui berbagai macam media komunikasi yang dapat menunjang Pembelajaran Jarak Jauh tahsin Al-Qur'an. Beberapa media yang digunakan para pengajar dalam Pembelajaran Jarak Jauh tahsin Al-Qur'an di SDIT Al Kahfi di antaranya; Whatssapp, Zoom Meeting, Google Meet. Dalam Pembelajaran Jarak Jauh tahsin AlQur'an di sekolah tersebut juga bekerja sama dengan orang tua murid agar siswa terbimbing selama Pembelajaran Jarak Jauh berlangsung.

Dengan mempertimbangkan berbagai hal di atas, maka artikel ini berupaya menjelaskan bagaimana implementasi metode Al Husna pada Pembelajaran Jarak Jauh tahsin Al-Qur'an di SDIT Al Kahfi Ciracas? Secara khusus bagaimana proses persiapan, pelaksanaan dan evaluasi pembelajaran yang dilakukan dalam Pembelajaran Jarak Jauh tahsin di SDIT Al Kahfi Ciracas? Dengan penjelasan ini diharapakan didapat evidence atau bukti bahwa pengajaran tahsin Al-Qur'an dapat dilaksanakan walaupun dalam kondisi Pandemi dengan menggunakan model Pembelajaran Jarak Jauh. Penelitian ini juga berupaya mengkonfirmasi bahwa metode tahsin Al-Husna adalah salah satu metode tahsin yang cocok untuk kalangan anak-anak dan tidak menutup kemungkinan juga untuk kalangan lainnya sebagaimana yang telah dijelaskan secara umum dalam Penggunaan Metode Al-Husna untuk Peningkatan Kualitas Membaca Al-Qur'an dalam Program Pengenalan Al-Qur'an di SMP Muhammadiyah 8 Surakarta Tahun Ajaran 2016/2017 (Hartono, 2017) ataupun kajian studi Al-Qur'an dalam aspek evaluasi dengan menggunakan media Internet seperti yang telah dijelaskan dalam Evaluasi Program Tahfidz Melalui Media Sosial di Yayasan Indonesia Berkah (Wajdi et al., 2020).

\section{B. Metode Penelitian/Metode Kajian}

Metode yang digunakan untuk menjawab pertanyaan di atas adalah penelitian kualitatif dengan pendekatan deskriptif analisis. Lexy J. Moleong mendefinisikan penelitian deskriptif kualitatif adalah penelitian yang bermaksud untuk memahami fenomena tentang apa yang dialami oleh subjek penelitian, misalnya perilaku, persepsi, motivasi, tindakan, dan lain sebagainya. Secara holistik dan dengan cara deskripsi dalam bentuk kata-kata dan bahasa, pada suatu konteks khusus yang alamiah dan dengan memanfaatkan berbagai metode alamiah (Moleong, 2018). 
Data primer dalam penelitian ini berasal dari pengambilan data melalui wawancara dan observasi. Wawancara dilaksanakan dengan informan narasumber yaitu staf koordinator keagamaan di SDIT Al Kahfi Ciracas. Peneliti langsung mewawancarai staf koordinator keagamaan yang mengarahkan guru-guru tahsin yang ada di sekolah tersebut dan mengobservasi keberlangsungan Pembelajaran Jarak Jauh pada mata pelajaran tahsin Al-Qur'an. Peneliti juga mewawancarai guru-guru tahsin yang secara langsung terlibat dalam Pembelajaran Jarak Jauh tahsin Al-Qur'an. Sementara observasi dilaksanakan langsung oleh peneliti dengan melakukan pengamatan secara langsung ke SDIT Al Kahfi Ciracas yang beralamat di Jl. H. Muhayang No.39 C, RT.11/RW.1, Rambutan, Kec. Ciracas, Kota Jakarta Timur, Daerah Khusus Ibukota Jakarta 13830. Wawancara dan observasi dilaksanakan pada Oktober dan November 2020.

\section{Hasil dan Pembahasan}

Setelah melaksanakan penelitian Implementasi Metode Tahsin Al Husna dalam Pembelajaran Jarak Jauh pada Masa Pandemi Covid-19 di SDIT Ciracas Jakarta Timur, dapat disampaikan beberapa hasil temuan dari penelitian ini sebagai berikut.

\section{Implementasi Metode Tahsin Al Husna melalui PJJ}

Implemetasi metode tahsin Al Husan meliputi tiga aspek yaitu persiapan dan perencanaan; dan pembelajarannya, yaitu; penguasaan huruf hijaiyyah, penggunaan sistem tanda baca, dan penggunaan kata kunci dan kode.

\section{a. Persiapan dan Perencanaan}

Penerapan metode Al Husna di SDIT Al Kahfi diawali dengan persiapan awal dalam bentuk perencanaan-perencanaan tertulis yang akan menjadi aturan teknis pembelajaran sebagai pedoman guru-guru tahsin untuk mengimplementasikan metode Al Husna dalam proses pembelajaran tahsin AlQur'an. Bapak Fajar Syahri Karim, S.Pd.I selaku staf bidang keagamaan yang mengkoordinir pembelajaran tahsin di SDIT Al Kahfi menyampaikan bahwa,

"Persiapan-persiapan yang menjadi langkah awal dari pembelajaran tahsin AlQur'an di SDIT Al Kahfi, sebagaimana pada umumnya para guru-guru tahsin mempersiapkan perencanaan-perencanaan tertulis mulai dari silabus, rencana pelaksanaan pembelajaran, program tahunan, hingga program semester. Semua pererencanaan-perencanaan tersebut yang akan menjadi aturan sebagai pedoman guru-guru tahsin menjalani proses pembelajaran tahsin Al-Qur'an." (Wawancara dengan Fajar Syahri Karim pada 31 Oktober 2020). 
Perencanaan pembelajaran dalam bentuk aturan-aturan yang terangkum dalam administrasi pembelajaran memang sangat diperlukan. Hal tersebut juga sebagai bentuk keprofesionalan guru dalam menjalankan tugasnnya sebagai pendidik yang profesional. Berdasarkan Peraturan Pemerintah Republik Indonesia No. 74 tahun 2006, diterangkan bahwa yang juga merupakan tugas profesional guru ialah mulai dari menyusun perangkat pembelajaran yang menjadi aturan serta pedoman dalam menjalankan kegiatan pembelajaran, melaksanakan pembelajaran, melaksanakan penilaian pembelajaran, melaksanakan program perbaikan dan pengayaan, melaksanakan analisis hasil penilaian dan melaksanakan tugas tambahan. Termasuk perangkat pembelajaran ialah kegiatan persiapan, yang meliputi kegiatan menyusun silabus, menyusun Rencana Pelaksanaan Pembelajaran (RPP), dan menyusun modul pembelajaran. Persiapan Pembelajaran Jarak Jauh yang menjadi administrasi para guru pra pembelajaran ialah:

\section{$\underline{\text { Silabus }}$}

Silabus merupakan garis besar dari materi pokok pembelajaran tahsin AlQur'an. Di dalamnya terangkum susunan tema materi pokok pembelajaran tahsin Al-Qur'an yang menjadi acuan materi bagi para pengajar tahsin ketika melaksanakan Pembelajaran Jarak Jauh tahsin Al-Qur'an. Pada bagian silabus ini, konten materi yang terangkum dalam silabus tidak ada perubahan dibandingkan silabus yang direncanakan pada pembelajaran tatap muka. Karena penyusunan silabus didasarkan pada indikator-indikator pencapaian yang menjadi turunan dari kompetensi inti dan kompetensi dasar. Sehingga konten materi yang tersusun dalam silabus tidak terpengaruh akibat dari diterapkannya Pembelajaran Jarak Jauh. Sedangkan materi pembelajaran tahsin yang tersusun dalam silabus didapat dari Yayasan Al Husna Indonesia, selaku pencetus sekaligus pemilik metode Al Husna. Silabus pembelajaran tahsin terbagi menjadi program tahunan, program semester dan RPP.

Program tahunan adalah rencana penetapan alokasi waktu satu tahun untuk mencapai tujuan yang telah ditetapkan. Penetapan alokasi waktu diperlukan agar seluruh kompetensi dasar yang ada dalam kurikulum seluruhnya dapat dicapai oleh siswa. Penentuan alokasi waktu ditentukan pada jumlah jam pelajaran tahsin dengan mempertimbangkan jumlah target pencapaian siswa pada pembelajaran tahsin Al-Qur'an. Program Tahunan berisi tentang garis-garis besar yang hendak 
dicapai dalam satu tahun dan dikembangkan oleh guru tahsin. Program ini dipersiapkan dan dikembangkan oleh guru sebelum tahun pelajaran dimulai, karena merupakan pedoman bagi keberlangsungan pembelajaran tahsin Al-Qur'an. Program tahunan memuat penjabaran alokasi waktu tiap-tiap standar kompetensi dan kompetensi dasar untuk tiap semester dan tiap kelas selama satu tahun pelajaran. Program tahunan selanjutnya dijabarkan secara rinci pada program semester.

Program semester merupakan rencana pembelajaran yang berisikan alokasi waktu dan ketercapaian selama satu semester. Isi dari program semester merupakan turunan dari program tahunan, sehingga penjabaran pada program semester lebih detail dari program tahunan. Program semester berisikan penjabaran pembelajaran di setiap pertemuannya.

Rencana pelaksanaan pembelajaran, atau disingkat RPP, menjadi acuan yang dipegang guru tahsin untuk melangsungkan kegiatan pembelajaran. RPP dibuat oleh pendidik untuk membantunya dalam mengajar agar sesuai dengan Standar Kompetensi dan Kompetensi Dasar pada hari dimana guru melangungkan pembelajaran. Adapun Rencana Pelaksanaan Pembelajaran (RPP) berisi perencanaan teknis di setiap pertemuannya pada pembelajaran tahsin AlQur'an. Hanya saja dalam RPP yang telah dirancang, hanya mencantumkan capaian materi yang akan disampaikan di setiap pertemuannya, dan belum memuat tentang metode penyampaian materi, media yang digunakan ataupun hal lain yang menjadi penunjang berlangsungnya pembelajaran tahsin. Pada perencanaan pembelajaran di bagian RPP untuk Pembelajaran Jarak Jauh, sedikit kurang karena perencanaan pembelajaran belum dituangkan menjadi rancangan tertulis, karena persiapan menghadapi Pembelajaran Jarak Jauh terlalu singkat. Sehingga persiapan perencanaan pembelajaran hanya disampaikan melalui pertemuan-pertemuan koordinasi guru tahsin-tahfizh.

Silabus yang diterapkan dalam Pembelajaran Jarak Jauh dalam pembelajaran tahsin Al-Qur'an dengan metode Al-Husna ini secara umum relatif sama dari segi kontennya. Adapun hal yang berubah adalah adanya penambahan media pembelajaran yang mengadopsi perangkat berbasis Internet seperti video sebagai media pembelajaran, aplikasi WhatsApp untuk mendistribusikan video kepada peserta didik dan penggunaan video-call baik dengan aplikasi WhatsApp ataupun Zoom untuk berdiskusi dan melakukan evaluasi. Selain itu, jika ada 
perubahan dari segi teknis prosedur pembelajaran terkait dengan metode Pembelajaran Jarak Jauh, maka koordinator metode tahfidz Al-Husna menyampaikan hal tersebut kepada para guru untuk diterapkan. Maka, dapat disampaikan di sini bahwa ada fleksibilitas silabus dalam rangka mengadopsi proses Pembelajaran Jarak Jauh ini.

\section{Sarana Penunjang Tahsin Al-Qur'an dengan PJJ}

Dalam pembelajaran tahsin Al-Qur'an diperlukan berbagai macam sumber daya penunjang keberlangsungan pembelajaran tahsin Al-Qur'an. Sumber daya penunjang pembelajaran tahsin Al-Qur'an di SDIT Al Kahfi mencakup beberapa hal. Mulai dari sarana dan prasarana serta sumber daya manusia dalam hal ini adalah guru sebagai pendidik pelajaran tahsin Al-Qur'an dan orang tua sebagai pembimbing siswa untuk belajar dari rumah.

Pelaksanaan Pembelajaran Jarak Jauh tahsin Al-Qur'an perlu ditunjang dengan berbagai sarana dan prasarana guna keberlangsungan pembelajaran tahsin Al-Qur'an meskipun harus dengan sistem Pembelajaran Jarak Jauh. Bapak Fajar Syahri Karim, S.Pd. mengemukakan tentang bagaimana persiapan sarana dan prasarana penunjang pembelajaran tahsin selama Pembelajaran Jarak Jauh,

"Beberapa sarana dan prasarana yang menjadi penunjang Pembelajaran Jarak Jauh tahsin selama ini di antaranya, alat komunikasi berupa smarthphone, fasilitas WIFI yang disediakan sekolah atau kuota internet untuk online, modul pembelajaran Al Husna, dan alat tunjuk untuk membantu fokus saat membaca." (Wawancara dengan Fajar Syahri Karim pada 31 Oktober 2020).

Sarana dan prasarana tersebut sangat diperlukan untuk keberlangsungan Pembelajaran Jarak Jauh tahsin Al-Qur'an. Berdasarkan pengamatan yang dilakukan peneliti ketika melakukan observasi terhadap Pembelajaran Jarak Jauh tahsin Al-Qur'an di SDIT Al Kahfi, persiapan pra-Pembelajaran Jarak Jauh tahsin Al-Qur'an adalah sebagai berikut: 1) Smartphone; 2) WIFI atau kuota internet; 3) Modul pembelajaran Al Husna; 4) Alat penunjuk; 5) Video pembelajaran; 6) Aplikasi Whattsapp; dan 7) Aplikasi Teleconference.

\section{Persiapan Sumber Daya Manusia}

Sumber daya manusia yang dimaksudkan dalam Pembelajaran Jarak Jauh tahsin Al-Qur'an ialah guru dan orang tua murid. Orang tua murid dilibatkan agar 
siswa lebih terbimbing saat belajar di rumah. Karena guru tidak memungkinkan membimbing secara langsung kepada siswa. Guru menjadi pendidik utama yang merencanakan, melaksanakan, serta mengevaluasi pembelajaran siswa di rumah. Guru tahsin yang direkrut oleh SDIT Al Kahfi memiliki standar tertentu agar bisa mengajarkan pembelajaran tahsin Al-Qur'an di SDIT Al Kahfi, diantaranya; Lulus atau sedang mengenyam pendidikan minimal S1 dengan diutamakannya yang berlatar belakang pendidikan atau memilki pengalaman mengajar, fasih membaca Al-Qur'an sesuai dengan kaidah dan hukum tajwid, memiliki hafalan Al-Qur'an minimal satu juz. Menurut keterangan dari Bapak Fajar Syahri Karim, S.Pd.I selaku koordinator tahsin tahfiz,

"Untuk pengajar tahsin kami memeberikan pembekalan atau pelatihan tentang pengajaran tahsin menggunakan metode Al Husna. Walaupun para guru tahsin sudah mampu untuk membaca Al-Qur'an secara tartil atau benar, tetapi mereka perlu pembekalan agar bisa mngejarkan Al-Qur'an dengan menggunakan metode tashin Al Husna ini." (Wawancara dengan Fajar Syahri Karim pada 31 Oktober 2020).

Selanjutnya dalam mempersiapkan guru-guru tahsin pada pembelajaran tahsin dengan metode Al Husna, para guru tahsin diberikan training pengajaran dengan metode Al Husna yang diberikan langsung oleh Bapak Fajar Syahri Karim, S.Pd.I selaku koordinator pembelajaran tahsin dan tahfiz yang juga memiliki sertifikasi pengajar metode Al Husna. Adapun dalam mempersiapkan para guru tahsin dalam menghadapi Pembelajaran Jarak Jauh tahsi Al-Qur'an, Bapak Fajar Syahri Karim, S.Pd.I selaku koordinator tahsin tahfiz di SDIT Al Kahfi melakuakan pengarahan tentang teknis Pembelajaran Jarak Jauh tahsin Al-Qur'an. Kemudian selama keberlangsungan pelakasanaan teknis Pembelajaran Jarak Jauh tahsin AlQur'an para guru tahsin juga rutin melakukan evaluasi jika ada kendala atau hambatan yang terjadi keberlangsungan Pembelajaran Jarak Jauh tahsin Al-Qur'an. Selain training dan pengarahan yang diberikan kepada guru-guru tahsin, para guruguru tahsin juga diberikan fasilitas atau wadah untuk terus senantiasa berintekasi dengan Al-Qur'an. Para guru diberikan target tilawah Al-Qur'an dalam sepekan. Terkait dengan hal tersebut Bapak Fajar Syahri Karim, S. Pd.I memberikan keterangan

"Hal tersebut ditujukan agar para guru senantiasa dekat dengan Al-Qur'an, karena mereka selaku guru yang mengajarkan membaca Al-Qur'an yang baik dan benar akan menjadi teladan atau contoh bagi para peserta didiknya. Karena akan sulit nantinya untuk mengajak para siswa untuk rutin melatih bacaan Al-Qur'an, jika 
gurunya tidak terbiasa dekat dengan Al-Qur'an." (Wawancara dengan Fajar Syahri Karim pada 31 Oktober 2020).

Dalam pembelajaran arak jauh tahsin Al-Qur'an, orang tua murid juga dilibatkan selama proses pembelajaran. Ketika di awal penetapan Pembelajaran Jarak Jauh, pihak sekolah mengadakan pertemuan online dengan orang tua murid yang dibuat per jenjang kelas. Pada pertemuan tersebut pihak sekolah mengajak orang tua murid untuk bekerja sama mendidik putra-putrinya selama belajar di rumah. Adapun dalam pembelajaran tahsin orang tua murid juga diajak untuk membimbing putra-putrinya selama Pembelajaran Jarak Jauh tahsin berlangsung. Hal tersebut sangat diperlukan agar siswa memiliki pembimbing langsung dalam pembelajaran tahsin. Karena guru-guru tahsin tidak bisa menjangkau siswa satu persatu untuk membimbing Pembelajaran Jarak Jauh tahsin tersebut.

\section{b. Pelaksanaan metode Al Husna dalam PJJ Tahsin}

Pelaksanaan metode Al Husna pada Pembelajaran Jarak Jauh tahsin AlQur'an yang ada di SDIT Al Kahfi menyesuaikan teknik yang sebagaimana konsep yang mendasari metode Al Husna itu sendiri, yaitu proses pembelajaran dilakukan untuk memperbaiki bacaan Al-Qur'an siswa dengan menggunakan teknik penguasaan huruf hijaiyyah, penggunaan sistem tanda baca, dan penggunaan kata kunci dan kode. Meskipun Pembelajaran Jarak Jauh harus diterapkan, teknik tersebut tetap dilaksanakan sebagaimana mestinya melalui pemanfaatan mediamedia yang dapat menunjang Pembelajaran Jarak Jauh tahsin Al-Qur'an, terutama media video pembelajaran tahsin Al-Qur'an. Karena hal tersebut merupakan standar pengimplementasian dari metode Al Husna. Tentunya menyesuaikan dengan penggunaan media-media yang ada.

\section{Penguasaan huruf hijaiyyah dengan metode scanning-story-saying}

Dalam penerapan metode Al Husna di SDIT Al Kahfi, hal pertama yang diajarkan kepada peserta didik adalah penguasaan huruf hijaiyyah. Dalam metode Al Husna pengenalan huruf hijaiyyah sedikit berbeda dibandingkan metode pada umumnya. Ini dapat dilihat dari jumlah huruf yang diajarkan. Pada metode yang umum, huruf yang diajarkan bisa mencapai tiga puluh huruf. Sedangkan pada metode Al Husna hanya berjumlah dua puluh delapan huruf. 


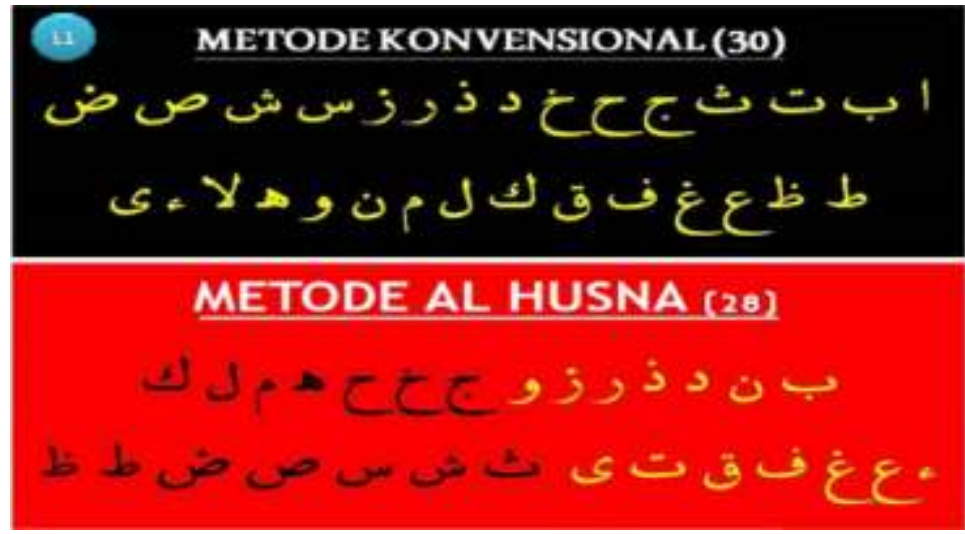

Gambar 1: Susunan Huruf Al Husna

Dalam metode Al Husna ada beberapa huruf yang tidak diajarkan dalam proses penguasaan huruf hijaiyyah seperti hiruf alif dan lam alif. Huruf tersebut bukan berarti dihilangkan, hanyasanya huruf-huruf tersebut diajarkan pada bahasan yang berbeda. Adapun penguasaan huruf hijaiyyah yang diajarkan pada pembelajaran tahsin Al-Qur'an di SDIT Al Kahfi, sebagaimana yang menjadi ciri khas dari metode Al Husna yaitu diajarkan dengan menggunakan cara scanningstory-saying.

\section{Scanning}

Proses scanning, merupakan proses di mana guru mengenalkan bentuk dan ciri dari huruf kepada peserta didik. Dalam proses scanning ada cara khusus dalam menunjuk bentuk dan ciri dari huruf yang sedang dikenalkan. Seperti beberapa contoh cara penunjukan ciri dan bentuk huruf berikut.

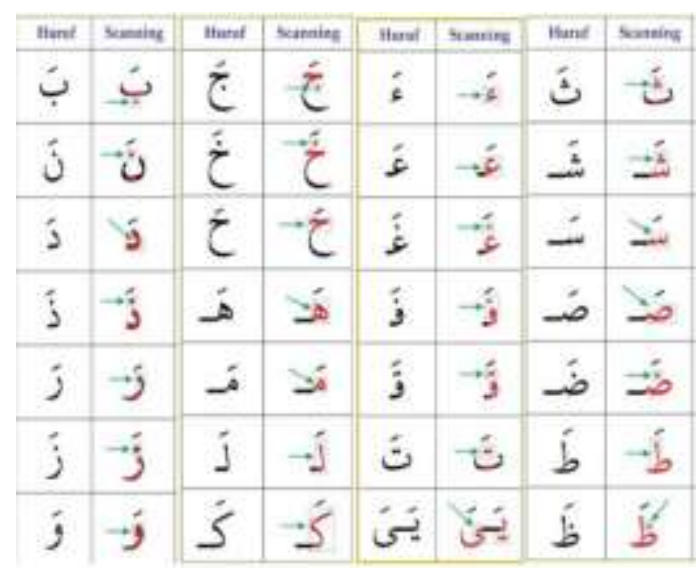

Gambar 2: Scanning Huruf 
Proses scanning dengan cara penunjukan khusus kepada ciri atau bentuk huruf seperti contoh di atas, ditujukan agar siswa dapan lebih fokus kepada ciri yang melekat pada huruf yang sedang di-scanning. Dengan begitu siswa akan lebih mudah untuk mengingat bentuk huruf hijaiyyah yang ada pada Al-Qur'an. Dalam video pembelajaran yang dibuat oleh guru tahsin, proses ini tetap dilakukan dengan cara guru merekam ke halaman yang sedang dipelajari sambil menunjuk dengan menggunakan alat penunjuk.

\section{Story}

Proses story, atau memberikan cerita atau analogi yang mudah dicerna oleh peserta didik merupakan tahapan setelah proses scanning dilakukan. dalam proses story ini siswa akan disuguhkan dengan berbagai macam perumpamaanperumpamaan unik yang menggambarkan ciri dari huruf yang sedang diajarkan. Seperti beberapa contoh berikut.

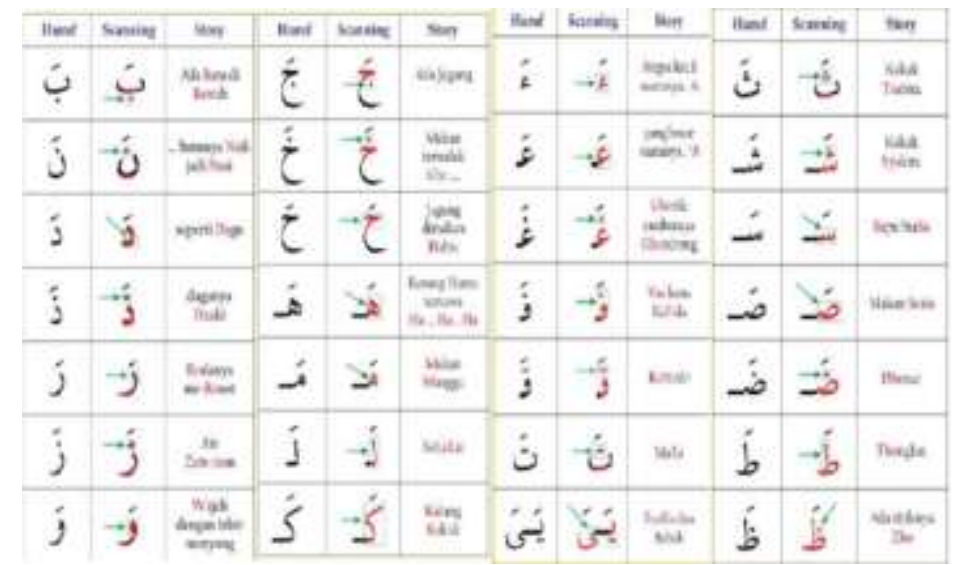

Gambar 3: Scanning dan Story Huruf

Pada tahapan story guru menyampaikan cerita berupa perumpamaanperumpamaan seperti diatas untuk memudahkan anak menangkap apa yang disampaikan oleh guru. Selain itu pemberian cerita dengan perumpamaanperumpamaan pada huruf-huruf hijaiyyah akan membuat pembelajaran lebih variatif. Sehingga siswa tidak bosan dengan pembelajaran tahsin Al-Qur'an. 


\section{Saying}

Selanjutnya adalah tahapan saying atau contoh pelafalan. Tahapan ini dilakuakan setelah guru menyampaikan story dari huruf atau bacaan yang sedang dipelajari. Setelah siswa sudah dapat menangkap dengan baik yang menjadi ciri materi yang sedang dipelajari barulah Saying dilakukan oleh guru dengan mencontohkan cara membaca yang benar sesuai kaidah yang berlaku. berikut merupakan panduan dari tahapan saying yang berupa cara pengucapan dari huruf hijaiyyah.

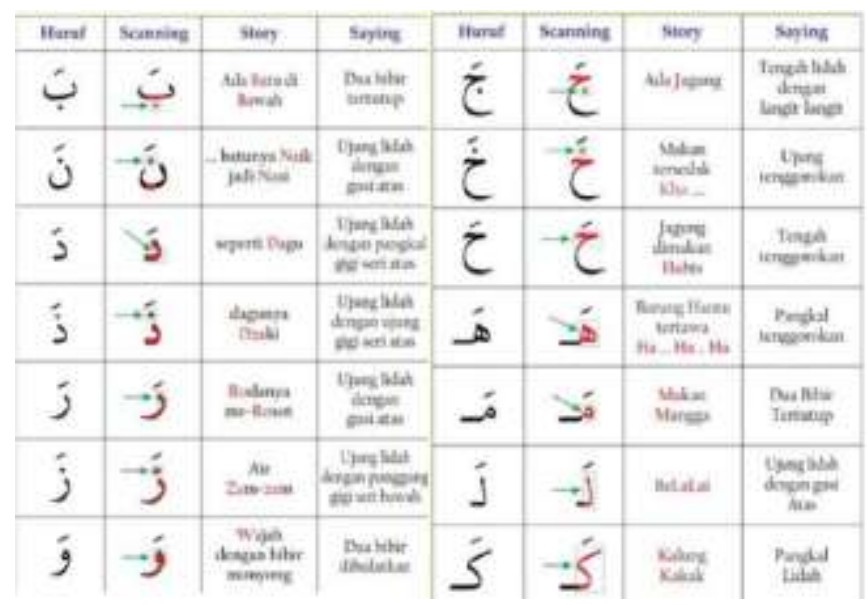

Gambar 4: Scanning Story Saying

\section{$\underline{\text { Penggunaan sistem tanda baca (Smart dobth) }}$}

Pada metode Al Husna penggunaan tanda baca difungsikan agar siswa dapat lebih mudah membaca Al-Qur'an sesuai dengan kaidah tajwid yang berlaku meskipun belum mengetahui teori dari hukum tajwid yang ada. Pada pembelajaran tahsin di SDIT Al Kahfi yang menggunakan metode Al Husna, guru mengejarkan kepada siswa membaca hukum bacaan hanya dengan melihat ciri dari tanda baca. Sehingga mereka lebih mudah untuk mengingat hukum bacaan dibandingkan harus menghafal teori hukum tajwid lebih dulu. Pada penggunaan sistem tanda baca ini, guru juga tetep menerapkan teknik Scanning-Story-Saying. Namun dalam praktiknya pada mushaf Al-Qur'an sistem tanda tersebut hanya terdapat pada mushaf rosm utsmani yang menggunakan standar penulisan timur tengah. Berikut adalah contoh penggunaan sistem tanda baca atau smart dobth. 


\begin{tabular}{|c|c|c|c|c|c|c|c|}
\hline Hunuf & Scamilas & Sery & Seying & Hurat & Saming & Stang & Syging \\
\hline ś & $\rightarrow-8$ & 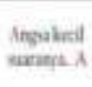 & $\begin{array}{l}\text { Pandal } \\
\text { tengprita }\end{array}$ & 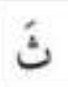 & & $\begin{array}{l}\text { lowak } \\
\text { Tuta }\end{array}$ & 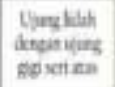 \\
\hline$\hat{s}$ & $-\varepsilon$ & 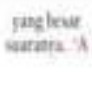 & $\begin{array}{c}\text { Timpit } \\
\text { tenpogitice }\end{array}$ & شì & $\rightarrow$ & kisk & 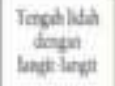 \\
\hline$\dot{\xi}$ & & 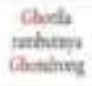 & $\begin{array}{c}\text { Uyng } \\
\text { enognitan }\end{array}$ & بنَ & & Sputaily & 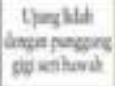 \\
\hline j & & $\begin{array}{l}\text { Vakes } \\
\text { Kefile }\end{array}$ & 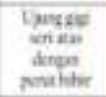 & صَّ & & Mhin Sind & 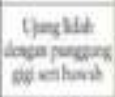 \\
\hline$\vdots$ & & Konoly & $\begin{array}{l}\text { Pundal } \\
\text { bute }\end{array}$ & & & Dhener & 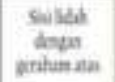 \\
\hline 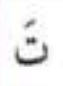 & -15 & seft. & 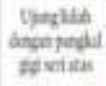 & $\dot{b}$ & $\rightarrow b$ & Therske & 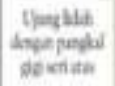 \\
\hline 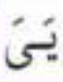 & & $\begin{array}{l}\text { Aallide } \\
\text { Matse }\end{array}$ & $\begin{array}{l}\text { Monyltilab } \\
\text { dingunlasgr } \\
\text { langt }\end{array}$ & $\dot{b}$ & É & 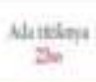 & 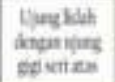 \\
\hline
\end{tabular}

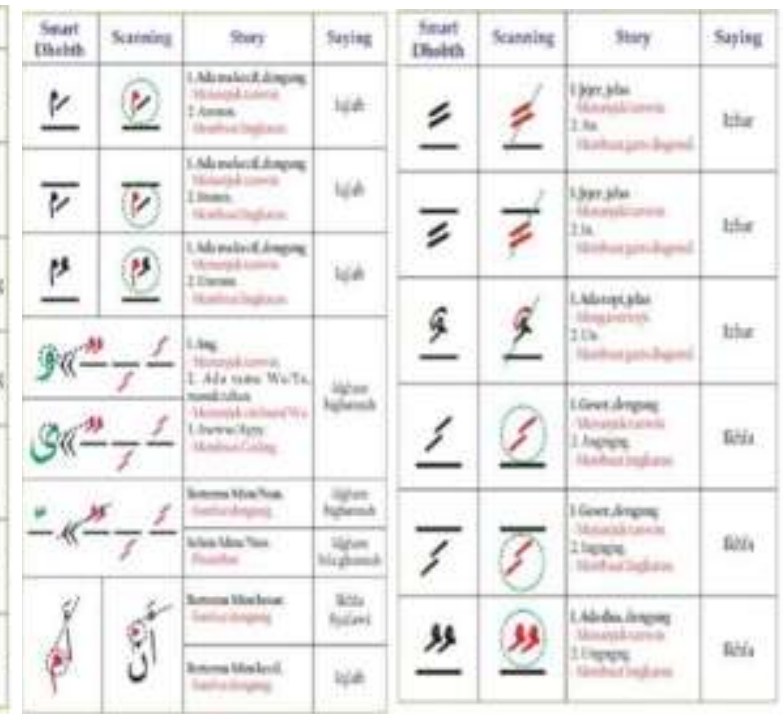

\section{Gambar 5: Smart Dobth}

\section{Penggunaan kata kunci dan kode}

Penggunaan kata kunci dan kode merupakan proses dalam pembelajaran tahsin metode Al Husna yang juga menjadi ciri khas dari metode tahsin tersebut. Kata kunci yang dimaksud adalah pengelompokan huruf-huruf hijaiyyah yang menjadi kunci-kunci dalam tahapan penguasaan huruf hijaiyyah. Huruf-huruf hijaiyyah dikelompokkan menjadi kunci-kunci berdasarkan kemiripan-kemiripan yang ada pada huruf-huruf hijaiyyah. Baik dari segi bentuk, makhraj, sifat, dan pengucapan huruf. Berikut merupakan contoh dari penggunaan kata kunci pada metode Al Husna.

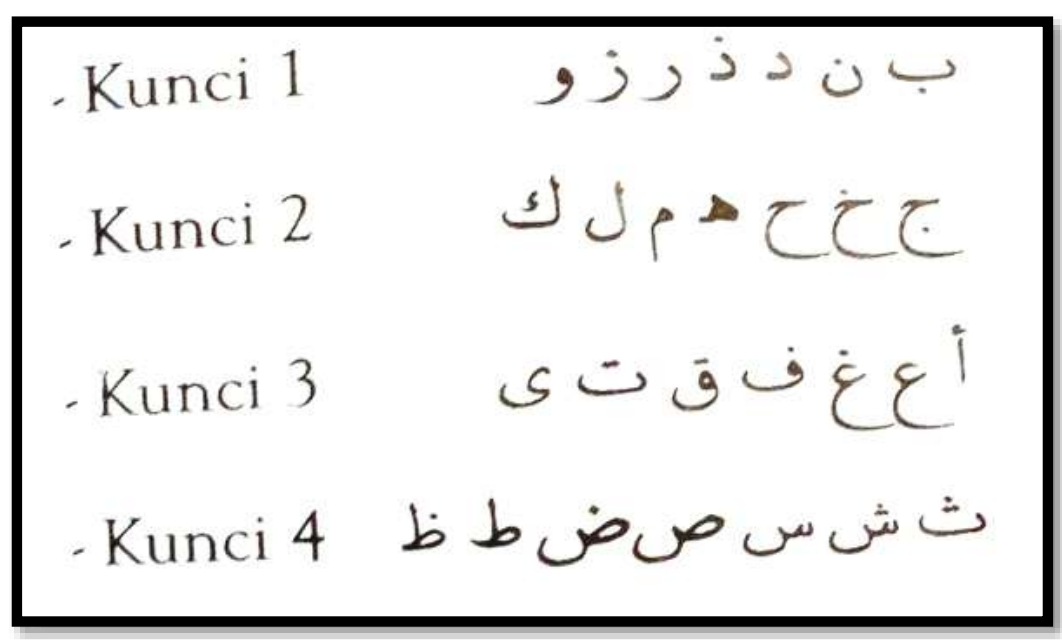

Gambar 6: Kunci Huruf 
Kemudian, selain menggunakan kata kunci, metode tahsi Al Husna juga menggunakan kode. Yang dimaksud kode dalam pembahasan ini adalah kode yang diberikan oleh pengajar dengan gerakan alat penunjuk pada kaidah-kaidah bacaan yang ada pada Al-Qur'an. Hal tersebut dapat membantu siswa mengingat kaidahkaidah bacaan Al-Qur'an meskipun mereka tidak menghafal kaidah-kaidah tersebut. Penggunaan kode tersebut juga tetap divariasikan dengan menggunakan teknik scanning-story-saying. Berikut merupakan contoh panduan penggunaan kode pada metode Al Husna.

\begin{tabular}{|c|c|c|c|c|c|c|c|}
\hline Huruf & Scanning & Story & Saying & Huruf & Scanning & Story & Saying \\
\hline قَا & فَ & 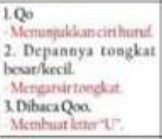 & $\begin{array}{c}\text { Dua } \\
\text { harakat }\end{array}$ & & & 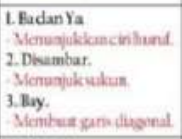 & $\begin{array}{l}\text { Dibaca } \\
\text { Lin }\end{array}$ \\
\hline & & 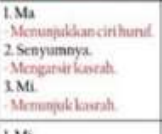 & $\begin{array}{l}\text { Turunkan } \\
\text { rahang } \\
\text { bawah }\end{array}$ & & & 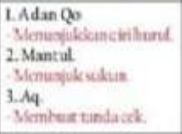 & $\begin{array}{l}\text { Dibuca } \\
\text { Qolqolah }\end{array}$ \\
\hline 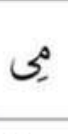 & 5 & 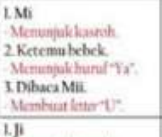 & $\begin{array}{c}\text { Dui } \\
\text { harakat }\end{array}$ & & & 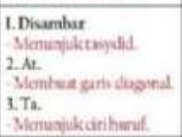 & $\begin{array}{l}\text { Dibaca } \\
\text { tasydid }\end{array}$ \\
\hline & $\frac{3}{7}$ & 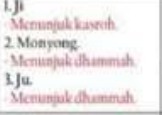 & $\begin{array}{c}\text { Bibir } \\
\text { dibulatkan }\end{array}$ & \multirow{2}{*}{ بـظُّنُ } & \multirow{2}{*}{ يَُّّنُ } & \multirow{2}{*}{ 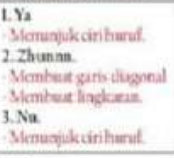 } & \multirow[t]{2}{*}{$\begin{array}{c}\text { di- } \\
\text { dengungkan }\end{array}$} \\
\hline \multirow{2}{*}{ نُو } & \multirow{2}{*}{ ز. } & 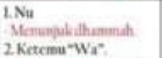 & \multirow{3}{*}{$\begin{array}{c}\text { Dua } \\
\text { harakat }\end{array}$} & & & & \\
\hline & & 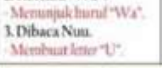 & & \multirow{2}{*}{ נم- } & \multirow{2}{*}{ D- } & \multirow{2}{*}{ 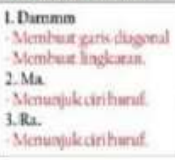 } & \multirow{2}{*}{$\begin{array}{c}\text { di- } \\
\text { dengungkan }\end{array}$} \\
\hline & & & & & & & \\
\hline
\end{tabular}

Gambar 7: Penggunaan Kode

Praktik yang dicontohkan oleh guru-guru tahsin Al-Qur'an di SDIT Al Kahfi pada penggunaan kode dalam mengajarkan kaidah-kaidah yang ada pada AlQur'an adalah, dimulai dari scanning bacaan yang berlaku hukum atau kaidah bacaan tertentu sambil diberikan kode dengan gerakan alat penunjuk oleh guru, kemudian guru memberikan story pada bacaan tersebut, setelah itu guru mencontohkan bacaan tersebut.

Semua teknik dan metode Al-Husna yang telah dipaparkan peneliti di atas dalam proses Pembelajaran Jarak Jauh (PJJ) diaplikasikan oleh para pengajar tahsin di SDIT Al Kahfi dengan melibatkan orang tua siswa. Terkait dengan Pembelajaran Jarak Jauh dari metode tahsin ini maka dapat digambarkan prosesnya sebagai berikut. Pertama, guru membuat video yang menjelaskan bagaimana cara membaca Al-Qur'an sesuai dengan materi di setiap pertemuan. Video tersebut kemudian dikirimkan kepada para peserta didik melalui grup WhatsApp tahsin. Video contoh 
dari guru tetap konsisten menjelaskan cara membaca materi dari modul pembelajaran tahsin Al Husna dengan mengaplikasikan teknik-teknik yang ada pada metode Al Husna mulai dari scanning-story-saying. Kedua, peserta didik diminta mempelajari materi dari modul pembelajaran tahsin Al Husna dengan bantuan contoh dari video yang dikirimkan oleh guru sebelumnya. Dalam bagian ini, orang tua siswa juga diminta terlibat untuk membatu siswa memahami materi dan kemudian membuat video siswa yang menunjukkan bagaimana siswa dapat mengulang cara membaca Al-Qur'an yang baik seperti yang telah dicontohkan oleh guru sebelumnya. Video siswa ini dikirim kepada guru sebagai bahan evaluasi. Bagian pertama dan kedua ini dilangsungkan sebanyak dua kali dalam seminggu dengan jadwal yang telah ditetapkan untuk setiap jenjang kelas. Ketiga, evaluasi hasil atau penguasaan siswa dengan penelaahan video siswa oleh guru. Guru memberikan feedback dengan voice-note yang dikirim via WhatsApp. Selain itu, setiap siswa memiliki kesempatan untuk video-call sebanyak dua kali dalam sebulan dengan guru untuk berdiskusi dan bertanya jika ada hal yang belum jelas. Dengan memanfaatkan media Internet, metode tahsin Al-Husna terlihat dapat tetap dijalankan dengan cukup baik walaupun dalam bentuk Pembelajaran Jarak Jauh.

\section{c. Evaluasi Pembelajaran Jarak Jauh Tahsin Al Husna}

Evaluasi Pembelajaran Jarak Jauh tahsin yang dilakukan di SDIT Al Kahfi Ciracas terdiri dari beberapa tahapan yaitu evaluasi harian, evaluasi tengah semester, dan evaluasi akhir semester. Hal ini dilaksanakan untuk memastikan penguasaan skil tahsin tidak hilang seiring dengan waktu. Semakin sering pelaksanaan evaluasi diberikan, diharapkan semakin baik skil pembacaan AlQur'an dapat melekat dalam pemahaman siswa didik. Berikut penjelasan secara lebih detail.

Evaluasi harian tahsin dilakukan di setiap pertemuan Pembelajaran Jarak Jauh tahsin. Evaluasi yang dilakukan adalah dengan cara, pengajar mengoreksi bacaan dari setiap peserta didik. Kemudian pengajar akan mengidentifikasi kesalahan-kesalahan yang ada dalam bacaan setiap peserta didik. Setelah itu pengajar akan memberikan hasil evaluasi bacaan kepada setiap peserta didik dalam bentuk rekaman suara yang berisi penjelasan tentang kesalahan-kesalahan yang perlu diperbaiki dari bacaan setiap siswa. Dalam proses Pembelajaran Jarak Jauh, bentuk evaluasi ini mengadopsi penggunaan media pembelajaran berbasis Internet 
dalam proses evaluasi pelaksanaan tahsin dengan metode Al Husna ini. Siswa membuat video yang menggambarkan penguasaan tahsin dan kemudian dievaluasi oleh guru. Guru memberikan evaluasi harian dengan voice-note yang dikirim via Aplikasi WhatsApp. Sehingga siswa tetap mendapatkan feedback atas capaian penguasaan tahsin model hariannya.

Evaluasi tengah semester pada Pembelajaran Jarak Jauh tahsin di SDIT Al Kahfi dilakukan pada pertengahan di setiap semester tahun ajaran. Evaluasi tengah semester juga dilakukan dalam bentuk praktik membaca bacaan yang telah ditentukan oleh tim pengajar tahsin. Teknis dalam pelaksanaan evaluasi tengah semester pada Pembelajaran Jarak Jauh tahsin, tidak jauh berbeda dengan evaluasi harian, yaitu peserta didik diminta mengirim video praktik membaca dari bacaan yang telah ditentukan pengajar. Kemudian pengajar akan mengoreksi seluruh bacaan peserta didik. Berbeda dengan evaluasi harian, evaluasi tengah semester diberikan dalam bentuk nilai berupa angka yang dituliskan dalam laporan hasil belajar tahsin dan tahfizh.

Evaluasi akhir semester pada Pembelajaran Jarak Jauh tahsin di SDIT Al Kahfi dilakukan di setiap akhir semester, baik semester ganjil ataupun genap. Evaluasi akhir semester juga dilakukan dalam bentuk praktik membaca bacaan yang telah ditentukan oleh tim pengajar tahsin. Teknis dalam pelaksanaan evaluasi akhir semester pada Pembelajaran Jarak Jauh tahsin, tidak jauh berbeda dengan evaluasi tengah semester, yaitu peserta didik diminta mengirim video praktik membaca dari bacaan yang telah ditentukan pengajar. Kemudian pengajar akan mengoreksi seluruh bacaan peserta didik. Hasil evaluasi akhir semester diberikan dalam bentuk nilai berupa angka yang dituliskan dalam laporan hasil belajar tahsin dan tahfizh dalam format PDF yang dapat dilihat oleh siswa dan orangtua siswa.

\section{Penutup}

Berdasarkan hasil penelitian tentang Implementasi Metode Al Husna pada Pembelajaran Jarak Jauh Tahsin di SDIT Al Kahfi Ciracas dapat disimpulakan beberapa temuan. Implementasi metode Al Husna pada Pembelajaran Jarak Jauh tahsin di SDIT Al Kahfi dilangsungkan melalui daring dengan menggunakan beberapa media komunikasi seperti WhatsApp, Zoom, Google Meet. Implementasi metode Al Husna pada pembelajaran tahsin terdiri dari beberapa tahapan, yaitu; persiapan dan perencanaan, pelaksanaan, evaluasi. 
Pada tahap persiapan, terdiri dari persiapan administrasi yang berupa gambaran perencanaan pembelajaran tahsin ke depan, mulai dari program tahunan yang berisikan target capaian selama satu tahun pembelajaran, kemudian diturunkan menjadi program semester yang berisikan target capaian dalam setiap semester pada tahun tersebut, dan rancangan perencanaan pembelajaran. Pada bagian RPP ini, sedikit kurang dikarenakan perencanaan Pembelajaran Jarak Jauh belum dituangkan dalam bentuk rancangan tertulis dikarenakan terbatasnya waktu untuk mempersiapkan PJJ Tahsin. Namun untuk mengatasi hal tersebut perencanaan tetap dibuat meskipun hanya disampaikan melalui pertemuanpertemuan koordinasi tahsin tahfizh. Perubahan yang mendasar adalah adanya adopsi media pembelajaran berbasis Internet dalam silabus metode tahsin. Persiapan selanjutnya ialah sumber daya pengajar, di mana para pengajar tahsin dipersiapkan dengan pelatihan dan juga pengarahan dalam menerapkan metode Al Husna pada pembelajaran tahsin, khususnya pada Pembelajaran Jarak Jauh. Selain itu ada juga persiapan sumber daya penunjang seperti: 1) Smartphone; 2) WIFI atau kuota internet; 3) Modul pembelajaran Al Husna; 4) Alat penunjuk; 5) Video pembelajaran; 6) Aplikasi WhatsApp; dan 7) Aplikasi Video-conference.

Adapun proses pelaksanaan Pembelajaran Jarak Jauh tahsin yang diterapkan adalah dengan pengajar mengirimkan video pembelajaran tahsin yang berisi tentang contoh cara membaca serta penjelasan dari materi yang sedang dipelajari. Dalam video pembelajaran tersebut juga diterapkan teknik pembelajaran yang menjadi ciri khas dari metode tahsin $\mathrm{Al}$ Husna yaitu scanning-story-saying. Pada proses pelaksanaan ini, selain membuat video pembelajaran, pengajar juga melakukan pertemuan daring melalui media teleconference ataupun videocall.

Sedangkan dalam evaluasi pembelajaran, dilakukan tiga kali evaluasi, yaitu; evaluasi harian, evaluasi pertengahan semester, dan evaluasi akhir semester. Evaluasi harian dilakukan dengan mengoreksi bacaan siswa pada setiap pembelajaran tahsin melalui media voice-note di aplikasi WhatsApp. Sedangkan evaluasi tengah semester dan evaluasi akhir semester dilakukan di pertengahan dan akhir semester dengan memberikan nilai pada laporan hasil belajar kepada orang tua peserta didik. Nilai diberikan dengan daring menggunakan format PDF.

Dengan demikian, pembelajaran tahsin Al-Qur'an terbukti dapat dijalankan dengan baik melalui metode Pembelajaran Jarak Jauh (PJJ). Hal ini menjelaskan bahwa pembelajaran tahsin yang seyogianya senantiasa berjalan dalam rutin harian atau mingguan tidak perlu terhenti dengan adanya Pandemi Covid-19 ini. Kesadaran sikap untuk 
beradaptasi dalam pembelajaran sebagaimana yang telah dibuktikan oleh SDIT SDIT Al Kahfi dengan segenap SDM nya perlu diapresiasi. Penggunaan media berbasis Internet juga terbukti menjadi media yang cukup akomodatif dalam memfasilitasi metode tahsin Al-Husna. Semoga pemanfaatan Internet untuk model Pembelajaran Jarak Jauh (PJJ) dalam pembelajaran tahsin ini dapat diduplikasi di dalam pembelajaran materi yang lainnya.

\section{DAFTAR PUSTAKA}

Amboro, K. (2020). Kontekstualisasi Pandemi Covid-19 dalam Pembelajaran Sejarah. Yupa: Historical Studies Journal, 3(2), 90-106.

Hartono, S. O. E. (2017). Penggunaan Metode Al-Husna untuk Peningkatan Kualitas Membaca Al-Qur'an dalam Program Pengenalan Al-Qur'an di SMP Muhammadiyah 8 Surakarta Tahun Ajaran 2016/2017. Universitas Muhammadiyah Surakarta.

Lilawati, A. (2020). Peran Orang Tua dalam Mendukung Kegiatan Pembelajaran di Rumah pada Masa Pandemi. Jurnal Obsesi, 5(1), 549-558.

Moleong, L. J. (2018). Metodologi Penelitian Kualitatif. Remaja Rosdakarya.

Santoso, Deri Teguh; Sari, R. P. (2020). Sosialisasi Penggunaan Aplikasi Video Conference Bagi Dosen Dan Mahasiswa Untuk Menunjang Pembelajaran Daring Di Masa Pandemic Covid-19. Universitas Muhammadiyah Mataram.

http://journal.ummat.ac.id/index.php/jmm/article/view/3110

Setiawan, D. I. (2015). Pelaksanaan Kegiatan Tahsin Al-Qur'an dalam Meningkatkan

Kemampuan Membaca Al-Qur'an Mahasiswa di Ma'had Sunan Ampel Al-Aly Universitas Negeri Maulana Malik Ibrahim Malang. Universitas Islam Negeri Maulana Malik Ibrahim Malang.

Supriadi, O. (2020). Peranan Kepala PAUD dalam Penyelenggaraan Pendidikan Sebelum dan Saat Terjadi Pandemi Covid-19. Jurnal Obsesi, 5(1), 841-856.

Wajdi, F., Fauzia, S., \& Hakam, A. (2020). Evaluasi Program Tahfidz Melalui Media Sosial di Yayasan Indonesia Berkah. Jurnal Studi Al-Qur'an, 16(1 SE-Articles). https://doi.org/10.21009/JSQ.016.1.05

Widyaningrum, G. L. (2020). WHO Tetapkan COVID-19 Sebagai Pandemi Global, Apa Maksudnya? Nationalgeographic.

https://nationalgeographic.grid.id/read/132059249/who-tetapkan-covid-19-sebagaipandemi-global-apa-maksudnya 